University of the Pacific

Scholarly Commons

4-1-2006

\title{
Prophecy and Porneia in Shenoute's Letters: The Rhetoric of Sexuality in a Late Antique Egyptian Monastery
}

Caroline T. Schroeder

Stanford University, cschroeder@pacific.edu

Follow this and additional works at: https://scholarlycommons.pacific.edu/cop-facarticles

Part of the History of Religion Commons, and the Religious Thought, Theology and Philosophy of Religion Commons

\section{Recommended Citation}

Schroeder, C. T. (2006). Prophecy and Porneia in Shenoute's Letters: The Rhetoric of Sexuality in a Late Antique Egyptian Monastery. Journal of Near Eastern Studies, 65(2), 81-97. DOI: 10.1086/504984

https://scholarlycommons.pacific.edu/cop-facarticles/88 


\section{PROPHECY AND PORNEIA IN SHENOUTE'S LETTERS: THE RHETORIC OF SEXUALITY IN A LATE ANTIQUE EGYPTIAN MONASTERY*}

CAROLINE T. SCHROEDER, Stanford University

\section{INTRODUCTION}

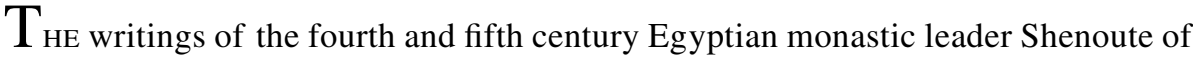
Atripe have often been cited as unparalleled resources for the study of the Coptic language, the tensions between pagans and Christians in late antique Egypt, and the history of early monasticism. Shenoute's community was situated in Upper Egypt on the other side of the Nile River from ancient Panopolis. Under his leadership, it purportedly grew to comprise thousands of male and female monks (in gender-segregated residences). For well over a century, scholars also have noted the prominence of sexual discourse in Shenoute's letters and monastic rules. The presence of such explicit language in monastic texts caused anxiety for some scholars near the turn of the twentieth century. They sought to provide explanations for the rhetoric. In a dissertation on Upper Egyptian monasticism, Paulin Ladeuze challenged Émile Amélineau's interpretation of this apparently unsettling language. Amélineau, charged Ladeuze, found the monks in the Shenoutean and Pachomian traditions to be less pure and disciplined than their counterparts in Scetis and Nitria. Ladeuze faulted Amélineau for asserting that the monks of Upper Egypt broke their vows of chastity with relative abandon and particularly with each other. Ladeuze attempted to rehabilitate the reputation of the Upper Egyptian tradition and argued that Amélineau had vastly overstated instances of sodomy and other "excesses" mentioned in the sources; according to Ladeuze, references to such behavior could even be later additions to the texts. ${ }^{1}$ The author of the first monograph devoted to Shenoute, Johannes Leipoldt, while dismissing the scholarly rigor of Amélineau and the objectivity of Ladeuze, nonetheless seemed to side

* I would like to thank Sheila McNally and Philip Sellew, the organizers of the "Living for Eternity" symposium at the University of Minnesota in February 2003, where I originally presented a version of this paper. I am indebted to the other symposium participants, respondents, and attendees and to Stephen Emmel for their thoughtful comments and questions. Last, I thank the JNES editors and its anonymous reader for their valuable suggestions.

${ }^{1}$ Paulin Ladeuze, Étude sur le cénobitisme Pakhomien pendant le $I V^{e}$ siècle et la première moitié du $V^{e}$

[JNES 65 no. 2 (2006)]

(C) 2006 by The University of Chicago.

All rights reserved.

0022-2968-2006/6502-0001\$10.00.
(Ph.D. diss., Université Catholique de Louvain, 1898) (Frankfurt am Main, 1961), pp. 327-50. Ladeuze cites a number of Amélineau's works, including: Histoire des monastères de la Basse-Égypte, Annales du Musée Guimet 25 (Paris, 1894); Monuments pour servir à l'histoire de l'Égypte chrétienne au IV siècle: Histoire de Saint Pakhôme et de ses communautés, Annales du Musée Guimet 17 (Paris, 1889); Resumé de l'histoire de l'Égypte (Paris, 1894); Monuments pour servir à l'histoire de l'Égypte chrétienne au $I V^{e}$ et $V^{e}$ siècles, Mémoires publiés par les membres de la Mission archéologique française au Caire 4, no. 1 (Paris, 1888); Monuments pour servir à l'histoire de l'Égypte chrétienne au $I V^{e}, V^{e}$, et $V I I^{e}$ siècles, Mémoires publiés par les membres de la Mission archéologique française au Caire 4, no. 2 (Paris, 1895). 
with the former on the subject of the monks' characters. ${ }^{2}$

Recent scholarship has rendered shaky Ladeuze's claim that reports of sexual indiscretions in Atripe have been greatly exaggerated. The publication of additional Shenoutean manuscripts, Stephen Emmel's codicological reconstruction of Shenoute's works, and Rebecca Krawiec's analysis of Shenoute's correspondence have all shed light on historical moments in Shenoute's monastery, moments in which both female and male monks broke their vows of chastity. ${ }^{3}$ Of course, this recent research does not establish that the ascetic men and women of Atripe were rather more lustful than their northern brethren. And only recently have scholars turned to Shenoute's references to male and female homoeroticism in the context of other late antique discourses of sexuality. ${ }^{4}$

In this article, I too take up the delicate question of the significance of sexuality in Shenoute's writings. I have not, however, chosen to ask, "Did they or didn't they?" with respect to the sexual lives of the monks in Shenoute's monastery. ${ }^{5}$ Instead, I suggest an alternative (but not exclusive) reading of the seemingly ubiquitous sexual references in a pair of Shenoute's letters, namely, his first extant letters. These two texts are now known collectively as the first volume of Shenoute's Canons, or Canon 1. I read Shenoute's references to sexuality as one element of another significant discursive element of Shenoute's writing, his self-representation as his community's prophet-a visionary and mediator cast in the mold of an Old Testament prophet. Shenoute's textual performance as a prophet in Canon 1 suggests another function for his sexual rhetoric, a function other than simply condemning sexual activity among ascetics. ${ }^{6}$ Shenoute's prophetic discourse constructs a

\footnotetext{
2 Johannes Leipoldt, Schenute von Atripe und die Entstehung des national ägyptischen Christentums, Texte und Untersuchungen zur Geschichte der altchristlichen Literatur 25 (Leipzig, 1903), pp. 147-49, esp. 147, n. 1.

${ }^{3}$ Stephen Emmel, Shenoute's Literary Corpus, 2 vols., Corpus Scriptorum Christianorum Orientalium (CSCO) 599-600, Subsidia 111-12 (Leuven, 2004); Rebecca Krawiec, Shenoute and the Women of the White Monastery (New York, 2002); Dwight W. Young, "Five Leaves from a Copy of Shenute's Third Canon, Le Muséon 113 (2000): 263-94; idem, Coptic Manuscripts from the White Monastery: Works of Shenute, 2 vols., Mitteilungen aus der Papyrussammlung der Österreichischen Nationalbibliothek (Papyrus Erzherzog Rainer), Neue Serie, Folge 22 (Vienna, 1993). Incidents of sexual contact between monks are also cited briefly in Peter Brown, The Body and Society: Men, Women, and Sexual Renunciation in Early Christianity (New York, 1998), p. 246, n. 22, citing Leipoldt, and Susanna Elm, 'Virgins of God': The Making of Asceticism in Late Antiquity, Oxford Classical Monographs (Oxford, 1994), pp. 305-6.

${ }^{4}$ Bernadette J. Brooten, Love between Women: Early Christian Responses to Female Homoeroticism (Chicago, 1996), pp. 348-50; Terry G. Wilfong, "'Friendship and Physical Desire': The Discourse of Female Homoeroticism in Fifth-Century CE Egypt," in Nancy Sorkin Rabinowitz and Lisa Auanger, eds., Among Women: From the Homosocial to the Homo-
}

erotic in the Ancient World (Austin, 2002), pp. 30429; Heike Behlmer, "Koptische Quellen zu (männlicher) 'Homosexualität',' Studien zur altägyptischen Kultur 28 (2000): 27-53.

5 I thank Derek Krueger for this formulation of the question of what actually transpired between monks. In his response to questions about his paper "The Representation of Same-Sex Monastic Cohabitation and Companionship in the Christian East: A Narrative Eros Reconsidered," American Academy of Religion, 24 November 2002, Krueger openly resisted answering the question "Did they or didn't they?" when examining texts about monks who lived or traveled as same-sex pairs.

${ }^{6}$ I have addressed this other, more literal, interpretation of Shenoute's sexual discourse in Canon 1 in "Purity and Pollution in the Asceticism of Shenute of Atripe," in M. F. Wiles and E. J. Yarnold, eds., Studia Patristica, vol. 35 (Leuven, 2001), pp. 142-47. In that article, I read Canon 1 with an eye to a different level of meaning, one in which the rhetoric of sexual purity and sexual transgression might have rung a very literal note in a monastery founded, in part, on the principle of celibacy. That article examines Shenoute's articulation of a purity code in which the sexual transgressions of a few monks could threaten the salvation of the entire community. Stephen Emmel has recently argued, on similar grounds, that the nature of the sins that so upset Shenoute may have been sexual and specifically homosexual (Stephen Emmel, "Shenoute the Monk: The 
relationship between God and the monastic community that is typologically modeled on the relationship between God and the people in the Christian Old Testament, a relationship that in turn was construed as that of husband and wife. For Shenoute, the sins of the monastery, like the sins of Israel, Jerusalem, or the nations, in the prophetic books of the Bible, are represented by the sin of fornication or porneia. By using passages, themes, and symbols from the prophetic books of the Bible, Shenoute constructs his late antique monastery as a feminine entity with significant theological, ideological, and social repercussions.

Before embarking on an analysis of Canon 1, however, a brief description of its contents is in order. As Stephen Emmel has established, Canon 1 is comprised of two letters that Shenoute wrote before he became the monastery's leader. They are "open letters" to the entire monastery, indicting the monks, including the current leader, for failing to address some sins that have been committed in the community. It is difficult to determine from the extant texts the precise nature of the sins that have been committed because Canon 1 survives in only fragmentary copies. Shenoute does mention sex repeatedly, as well as theft and disobedience, but his primary concern seems to extend beyond the initial sins that were committed. He focuses on the failure of the community, and particularly the monastic father, to punish the monks involved sufficiently. The opening of the first letter has been lost, but the first extant folio contains a recitation of some of the community's monastic rules. Most of these rules deal with sex, sexual desire, or potentially erotic situations, and others address theft and deception. ${ }^{7}$ In addition to lengthy homiletical passages, the first letter also contains accounts of Shenoute's arguments with the father of the monastery over what has transpired. In one account, Shenoute chastises his superior for refusing to hold people accountable for their sins. The father refuses to believe Shenoute's accusations of transgressions by monks and instead believes another monk, who denies that there has been any wrongdoing. Shenoute calls the other monk a liar and reports with some disgust that the father asked him, "We do not know with assurance who it is who has sinned, do we?"8 The letter ends with allegories Shenoute uses to describe the community's dire spiritual state, such as one in which he compares the sinners in the monastery to people in a pit who will not take assistance from one who offers it. ${ }^{9}$ The beginning of the second letter is also lost. Much of the remaining material consists of additional allegories about God's judgment on the community for its sin. As in the allegories in the first letter, Shenoute

Early Monastic Career of Shenoute the Archimandrite," in Maciej Bielawski and Daniël Hombergen, eds., Il monachesimo tra eredità e aperture: Atti del simposio "Testi e Temi nella Tradizione del Monachesimo Cristiano" per il $50^{\circ}$ anniversario dell'Istituto Monastico di Sant'Anselmo, Roma, 28 maggio-1 ${ }^{\circ}$ giugno 2002, Studia Anselmiana 140 [Rome, 2004], pp. 160-61).

7 Shenoute, Canon 1, XC 7-8, unpublished (Österreichische Nationalbibliothek, Vienna, Papyrussammlung, koptisch [hereafter AT-NB] 9101 r/v). See also my article, "Purity and Pollution," pp. 143-44 and Emmel, "Shenoute the Monk," pp. 164-65. The collection abbreviations (for example, AT-NB) and codex sigla (for example, $\mathrm{XC}$ ) used here correspond to the collection abbreviations used by Emmel (Shenoute's Literary Corpus, vol. 1, pp. 39-45) and the standard White Monastery library codex sigla; for a concordance of the sigla of codices containing Shenoutean texts with their locations, see Emmel, Shenoute's Literary Corpus, vol. 2, pp. 987-1000.

8 Shenoute, Canon 1, YW 80, unpublished (Bibliothèque national de France, Paris, Copte [hereafter FR-BN] $130^{2}$ fol. 2v): паї єтхıьол мпємто

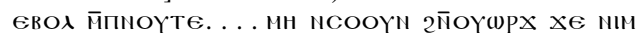
пєнтаст्р-новє; cf. Emmel's discussion of this passage in "Shenoute the Monk," p. 161, n. 28.

9 This particular example of the pit occurs in YG 128-29 in Alla I. Elanskaya, The Literary Coptic Manuscripts in the A. S. Pushkin State Fine Arts Museum in Moscow (Leiden, 1994), pp. 234-35; English translation, ibid., pp. 237-38. Notably, the help offered to the people in the pit is "the teaching of the scriptures." This section of allegories spans YG 124-25 to XB 142. See also Emmel, "Shenoute the Monk," p. 169. 
draws on images, motifs, and outright passages from Psalms, Proverbs, Job, Lamentations, and the prophetic books of the Bible, including Hosea, Jeremiah, Malachi, and Joel. ${ }^{10}$ Thus, Shenoute's allegories in both letters seem to be modeled in part on the genre of the biblical judgment oracle. ${ }^{11}$ The second letter contains another description of a conversation between Shenoute and the father of the monastery. Shenoute here denies wishing to lead the monastery himself. ${ }^{12}$ The entire volume of Canon 1 concludes with a note that the letters have been preserved for the continuing edification of the monks; it instructs all monks to read these letters four times a year. ${ }^{13}$

When reading Canon 1, these monks encountered a charismatic figure who mirrored other recognizable characters from their traditions and their scriptures. Shenoute combined prophetic and monastic sexual discourses to provide a critique of the community grounded in two authoritative traditions-biblical prophecy and Christian asceticism. This article begins by demonstrating the ways in which the letters of Canon 1 constitute a literary performance modeled on the prophetic books of the Bible in both style and substance. I then examine the use and confluence of prophetic and monastic sexual discourses in these two letters and conclude with an analysis of some of the social and ideological implications of the theological and hermeneutical developments in Canon 1. This is designed to begin, rather than end, a discussion on some very rich issues in Shenoute's writings, issues that deserve significant further research. ${ }^{14}$

\section{Shenoute as a "Peripheral Prophet"}

In Emmel's illuminating description of Canon 1, he characterizes the letters as texts of monumental importance for understanding Shenoute's career. The letters, he writes, describe "a major incident in Shenoute's life, one that might have established almost at once his authority as a prophet, a strict ascetic, a learned man, and an author," in the eyes of the community. ${ }^{15}$ I certainly concur with Emmel's observations, and I would also take his conclusions a step further to argue that the texts themselves are a part of Shenoute's prophetic self-representation. Specifically, the letters of Canon 1 fashion for Shenoute an identity as a charismatic figure in the tradition of the biblical Ephraimite prophets. Shenoute functions

10 Shenoute also utilizes language and themes from the New Testament. One of his allegories is an extended exegesis of 2 Cor. 11:14-15. See my article, "Purity and Pollution," p. 146.

11 For a review of this genre or literary form in the Hebrew Bible, see Robert R. Wilson, Prophecy and Society in Ancient Israel (Philadelphia, 1980), pp. 14143. The judgment speech, or oracle, includes a statement about the "commissioning of the messenger" (the prophet), an accusation of a transgression that remains unpunished, and an "announcement of judgment based on the accusation." The announcement usually comes in the "form of a direct address" to the community.

12 Shenoute, Canon 1, YG 220-22, unpublished (FR-BN $130^{2}$ fols. 46r-47r). See the citation, translation, and discussion in Emmel, Shenoute's Literary Corpus, vol. 2, p. 562, and idem, "Shenoute the Monk," p. 171.
13 Shenoute, Canon 1, YW 209-12 in Henri Munier, ed., Manuscrits coptes: catalogue général des antiquités égyptiennes du Musée du Caire nos. 9201-9304 (Cairo, 1916), pp. 115-18; idem, XC frg. 2, unpublished (FR-BN $130^{2}$ fol. 117); an English translation of relevant passages appears in Emmel, Shenoute's Literary Corpus, vol. 2, pp. 562-63.

14 For example, I have by necessity bracketed the difficult question of the form of Shenoute's own biblical text: whether Shenoute used a preexisting Coptic translation of the Septuagint; whether Shenoute (who likely knew Greek) translated the Septuagint into Coptic as he wrote; and the role Shenoute, or his monastery, played in the production of Coptic versions of the Christian Old Testament.

15 Emmel, Shenoute's Literary Corpus, vol. 2, p. 562 . 
more specifically as a "peripheral prophet" who stands outside of the community's primary religious and political authority system and speaks to the community from a marginal, but not wholly outside, position. In developing this prophetic identity, Shenoute not only cites biblical passages and interprets biblical texts for application to the monastery's situation, but he also adapts for his own purposes symbolic imagery found in the prophetic books, and he uses the rhetorical strategies of the peripheral prophets in the biblical tradition. Through his texts, Shenoute acts out several key characteristics of prophetic activity. $\mathrm{He}$ models the literary representations of his speech and actions on the ancient prophets. Through the letters of Canon 1, he establishes his own authority as prophet for the monastery.

In his study of ancient Near Eastern prophecy, Robert R. Wilson has identified several principal characteristics of peripheral prophets. First, the peripheral prophet is a recognized member of the community to whom he speaks, but he is situated on the periphery of the community's main institutions of political and religious power; in other words, he himself is not a central authority figure. Such figures may also have a small community of likewise "peripheral" supporters. Since the community shares a general respect for prophetic revelation, peripheral prophets can expect a certain level of authority and respect, despite their somewhat marginal social position. Moreover, peripheral prophets often use their charismatic authority to improve their social status in the community. ${ }^{16}$ Second, the prophet acts as an intermediary between God and the community through claims of direct, divine speech flowing from God through the prophet, as the intermediary; the prophet literally speaks for God and communicates visions from God to the community. ${ }^{17}$ Third, the peripheral prophet operates in the manner of a Mosaic prophet, who, like Moses, both gives and interprets God's law. ${ }^{18}$ Fourth, the peripheral prophet often uses prophetic statements to "condemn the religious establishment and advocate reforms" for the society, particularly with respect to the community's understanding of and adherence to the covenant and the law. ${ }^{19}$ Finally, peripheral prophets can be subsumed into the central hierarchy of their society, but they and their supporters are also frequently opposed or persecuted by the central religious and political establishments. ${ }^{20}$ Shenoute cultivates each of these characteristics in Canon 1, at times by interpreting passages and motifs from the prophetic books and applying them to his own community. Additionally, many of Shenoute's own prophetic judgments against the monastery in Canon 1 use themes and symbols common to the biblical prophets' judgment oracles against Jerusalem, Judah, and Israel.

In both letters of Canon 1, Shenoute presents himself as a marginalized and somewhat embattled figure in the community and hence as embodying both the first and fifth aspects of a peripheral prophet. He is without influence over the primary decision-makers in the community and is even scorned by them and others. As Emmel has argued, Shenoute originally composed both letters in Canon 1 from a physical standpoint somewhat removed from the central monastery. The letters describe events that occurred while Shenoute lived in the residence, but at some point during the conflicts narrated in Canon 1, Shenoute moved out of the main residential area. He wrote these letters as an affiliated anchorite living in the nearby desert. In one account of his dispute with the monastery's leader,

16 Wilson, Prophecy and Society, pp. 69-72.

17 Ibid., pp. 144-45, 235-36.

18 Ibid., pp. 157-64, 237.

19 Ibid., p. 195 (regarding the particular example of Elijah); see pp. 71-73 for this aspect of prophecy more generally.

20 Ibid., pp. 73-76, 194-95, 197, 244-46. 
Shenoute described his intentions to leave the communal residence and promised, "Behold, I say that if the Lord provides the means for me to do so, I determine that I shall not eat bread in fellowship (with you) until I go before God (die)." ${ }^{21}$ In moving to the desert, Shenoute followed a tradition that was unusual neither for this time nor for this particular monastery, since the monastic rules Shenoute cites in later writings discuss the requirements for anchorites affiliated with the community. ${ }^{22}$ Given the proximity of the monastery's current archaeological site to cells in the outlying desert, it also seems likely that Shenoute did not move terribly far away from the main monastic complex. Thus, Shenoute's relocation from the main residence to a solitary cell was not a complete removal from the community, either socially or geographically. His promise never to "eat in fellowship" with his colleagues again was as much a rhetorical move as a physical one. His vow rhetorically and politically distanced himself from the monastic leadership.

Shenoute returns to the trope of isolation and rejection several times in Canon 1 but particularly notably in a passage deep inside the second letter. He charges that most of his fellow monks have "turned up their noses" at him and have refused to believe his words about the consequences of "uncleanness and pollution" that have been committed in the monastery. ${ }^{23}$ This accusation introduces a Shenoutean "judgment oracle" against the monastery. His description of the monastery's lamentable state is a pastiche of images from Isaiah, Malachi, Jeremiah, and the Gospel of Matthew. Using a symbol prominent in Jeremiah, Shenoute describes a "destroyer" intent on decimating a grove of trees. This story is a metaphor for something that has "killed" the monastery's own "sons and daughters violently." ${ }^{24}$ Shenoute does not mechanically and precisely reiterate Jeremiah's story. Yet his choice of language and symbolism nonetheless recall Jeremiah's proclamations that a destroyer would lay waste to the cities, towns, valleys, lands, and peoples who defied the Lord. ${ }^{25}$ Shenoute's destroyer approaches a tree standing near a forest. Using an ax, he hacks the shoots and branches off of the tree and evokes multiple biblical images, such as Jer. 5: 10, when Israel's branches are stripped away; Isa. 10:34 when the Lord uses an ax to chop down the branches and trees of Assyria and the forests of Lebanon; or Matt. 3:10 in which an ax lies on the roots of some trees waiting to be wielded against all that do not bear good fruit. In Shenoute's version, the destroyer then returns and burns the shoots and branches, even most of the tree, calling to mind Isa. 10:16-19, in which the Lord burned "the glory of his forest and his fruitful land," so that few trees remained, or Jer. 5: 14, in which the Lord's words became fire, the people became wood, and the Lord burned through Israel. Shenoute's allegorical judgment concludes with a nod to Isa. 11:1 and the root of the stump of Jesse. He declares that all that shall remain after the inferno is a root that sat in a little moisture and that bears some green shoots above it. ${ }^{26}$ This vision also

21 Shenoute, Canon 1, YW 78, unpublished (FR-BN $130^{2}$ fol. $\left.1 \mathrm{v}\right)$ : ЄІ 2 ннте хоєı⿻ †өє naї †тш⿻ мммої єтм̄трдоүєм-оєıк

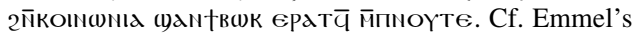
treatment of this section of Canon 1 in "Shenoute the Monk," p. 163.

22 For example, the rules in Shenoute, Canon 3, YA 310-11 in Johannes Leipoldt, Sinuthii Archimandritae Vita et Opera Omnia, 3 vols. (numbered 1, 3, 4), CSCO 41, 42, 73, Scriptores Coptici (SC) 1, 2, 5 (Paris, 1906-13), vol. 4, pp. 120-21.
23 Shenoute, Canon 1, YG 173 in Amélineau, Euvres de Schenoudi: texte copte et traduction française, 2 vols. (Paris, 1907), vol. 1, p. 446. Shenoute speaks of himself in the third person in this passage. See also Emmel, "Shenoute the Monk," p. 170, esp. n. 57.

24 Shenoute, Canon 1, YG 174-75 in Amélineau, Euvres, vol. 1, p. 447.

${ }^{25}$ Cf. Jer. 4: 7; 6:26; 15:8; 48:8-32; 51:56.

26 Shenoute, Canon 1, YG 175-78 in Amélineau, Euvres, vol. 1, pp. 447-49. 
resembles the judgment oracle of Mal. 4:1, which proclaims that all evildoers will burn, leaving behind neither root nor branch. Shenoute's prophetic and fiery image of judgment and punishment follows his narrative of his rejection by his people, suggesting that he might be read as following in the footsteps of prophetic figures such as Jeremiah and Isaiah, who were also at times rejected by a disbelieving community.

In characterizing himself as marginal and misunderstood, Shenoute does take on some risk. His arguments could be dismissed by his fellow monks as precisely that-marginal. But in Shenoute's favor stands the long and established tradition of prophets misunderstood and even persecuted by central religious and political authorities. In conforming to this biblical type, Shenoute enhances his own moral authority. And in emphasizing his rejection, he distances himself from what he argues is the ineffective, and even corrupt, administration of the monastery.

Shenoute's judgments also expose another aspect of Shenoute's prophetic self-fashioning, namely, his self-representation as a Mosaic prophet who provides and interprets the law for his community. As a Mosaic prophet, Shenoute criticizes his community for breaking God's law or violating its covenant with the Lord. Covenantal language is particularly prominent in the book of Jeremiah, where a primary concern is the community's breach of its covenant with God. ${ }^{27}$ Shenoute, following Jeremiah, uses covenantal language to characterize sins committed in the monastery.

Shenoute first acts as a provider and interpreter of God's law early in Canon 1. In a lengthy intertextual exegesis of Jer. 6:11, he weaves together the book of Jeremiah and the monastic rules. In Jeremiah, God's wrath falls on Israel for breaking the covenant and violating God's law, specifically for neglecting God's "word" and rejecting his "teaching" (6:19). Jer. 6:11 reads, "But I am full of the wrath of the Lord; I am weary of holding it in. Pour it out on the children in the street, and on the gatherings of young men as well; both husband and wife shall be taken, the old folk and the very aged." Shenoute first quotes this passage in slightly different form: "I increased my anger, I held it back," and "I will pour out

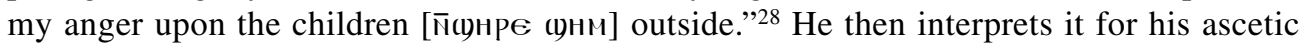
audience, claiming that the passage "is not difficult to understand." God's wrath will fall upon the monastery because it has broken the monastic rules. God will pour out his anger over children who remain in "defilement and pollution," but he will restrict his anger for those who repent. ${ }^{29}$ Shenoute continues:

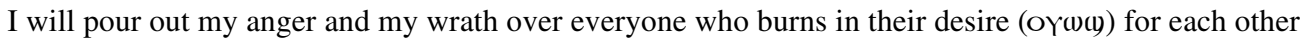
or also for a junior monk (оү(унре (унм), in a polluted desire (епөүмід), whether male or female. I will not spare any who kiss each other on the mouth in a polluted desire (€пөүMId), whether he is great or small. I will pour out my anger and my wrath over all men who lie down with each other according to the lawlessness of Sodom. I will not spare anyone who dares to despoil himself with his own hands in polluted and wicked work. ${ }^{30}$

Shenoute's Jeremiah is presented here as quoting almost precisely the language of the monastic rules Shenoute cited at the beginning of his letter. Some of these rules read,

27 Wilson, Prophecy in Israel, pp. 236-37; Jack R. Lundbom, Jeremiah 1-20: A New Translation with Introduction and Commentary, The Anchor Bible 21A (New York, 1999), p. 129.

28 Shenoute, Canon 1, XC 14 in Leipoldt, Opera
Omnia, vol. 3, p. 196.

29 Shenoute, Canon 1, XC 15-16 in Leipoldt, Opera Omnia, vol. 3, pp. 196-97.

30 Shenoute, Canon 1, XC 16 in Leipoldt, Opera Omnia, vol. 3, pp. 197-98. 
"Cursed is the person who will kiss a junior monk (оүсунеє (унм) with desire (оүепіөүміג). Cursed is everyone who will kiss or who will embrace each other with

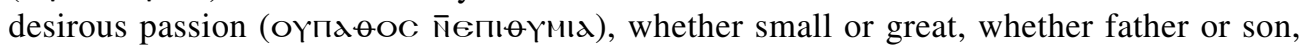
whether male or female. ..."31 These rules also prohibit masturbation, lying down on top of each other, and having sex with junior monks, activities that are similarly addressed in Shenoute's exegesis of Jer. 6:11.32 As I have discussed elsewhere, in much of this section, Shenoute maintains the speaking voice of the Lord. ${ }^{33} \mathrm{He}$ in effect expands the original biblical passage to encompass the monastic rule; he does not simply comment on a text he has quoted. By combining the language and genres of monastic rules and scriptural prophecy, Shenoute has transformed the monastic rules from a text of human authorship into the direct commands of the Lord through Shenoute, who acts as a prophet in the role of a new Jeremiah. ${ }^{34}$ The monastic rules become an expression of the law and the covenant between God and his people.

Shenoute explicitly invokes covenantal language later in the letter, when he again takes up several issues raised by the monastic rules he quoted at the beginning of the letter. This section begins with an allegory about sinners that draws on a symbol common to the Psalms, Proverbs, and prophets: a deep pit. Some people have fallen from an elevation down into the depths of a pit. Shenoute then describes the sinners using language very similar to the rules cited at the beginning of the letter. The people of the pit are:

[T]hose who defiled your sons and daughters, those who have become effeminate (lit. soft, Mdגdкос) among you, and those who lie down with men, those who commit many forms of defilements and pollutions, those who are thieves and liars and who swear falsely and who conduct themselves deceitfully among you, from male to female, and from male junior monk to female junior monk. ${ }^{35}$

Shenoute characterizes these transgressions of the monastic rules as "lawlessness" (aromid). His condemnation climaxes with a line taken from Hos. 6:10, where he conflates his own judgment with that of the prophet. Citing "the word that is written," Shenoute writes, "They committed lawlessness in the house of Israel. I saw in your dwelling-place fornication (порніх)." 36 (Hos. 6:10 reads, "In the house of Israel I have seen a horrible thing; Ephraim's whoredom is there, Israel is defiled." ${ }^{37}$ ) Shenoute further accuses members of

31 Shenoute, Canon 1, XC 7, unpublished (AT-NB

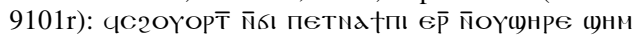

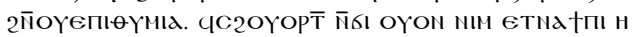

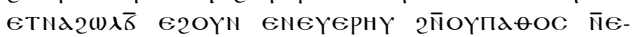
пюүмід еІте коүї еІте ноб еІте еІшт еІте (унре EITE 2OOYT EITE с2IME.

32 The list of rules appears in fols. XC 7-8 (unpublished, AT-NB $9101 \mathrm{r} / \mathrm{v}$ ). Regarding the exegesis of Jeremiah, in addition to XC 15-16, see XC 24 in Leipoldt, Opera Omnia, vol. 3, p. 203. See also Emmel, "Shenoute the Monk," p. 167. Shenoute provides a similar list of prohibited sexual activity in Canon 4 (see Wilfong, "Friendship and Physical Desire,", p. 316).

${ }^{33}$ See again my article, "Purity and Pollution," p. 144.

${ }^{34}$ Summarizing the work of several literary theorists, Elizabeth A. Clark has described intertextuality as an occasion "in which one text is 'read' in light of other explicitly or implicitly suggested texts, and in which both text and intertext are transformed by their new positioning"; Clark, "Ideology, History, and the Construction of 'Woman' in Late Ancient Christianity," Journal of Early Christian Studies 2 (1994): 164.

35 Shenoute, Canon 1, XC 59 in Munier, Manuscrits coptes, pp. 103-4.

36 Ibid.

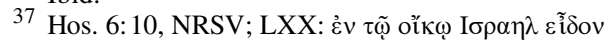

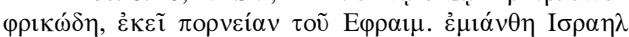

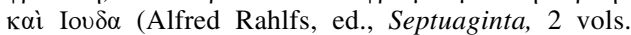
[Stuttgart, 1935], vol. 2, p. 495); Akhmimic: zмйнї

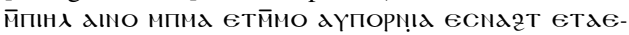
фралм те аухигме мбы пинд (Walter Till, ed., Die achmîmische Version der zwölf kleinen Propheten [Codex Rainerianus, Wien], Coptica 4 [Copenhagen, 1927], pp. 12-13). 
the community who have "defiled" themselves in this way of breaching their covenant with God: "They supported their lawlessness with a false covenant. . .."38

Shenoute returns to the language of the law in his second letter, where he summarizes his overall message with a call to return to God's law: "Let us not be a stranger to God and his law and all of these words, so that we will not be too late for the eternal life." ${ }^{9} 9$ Thus, Shenoute believes the goal of monks to be adherence to God's law. The monastic rules embody the covenant between God and the ascetic community. Implicit in this monastic covenant, as in the biblical covenant, is the promise of God's favor. Monks who adhere to the covenant of monastic obedience shall receive "eternal life." But monks who break the covenant with their lawless disregard for the rules risk God's punishment.

When Shenoute pronounces judgments upon the monastery, he forcefully articulates another element of standard prophetic rhetoric. He maintains that his authority to speak and write in such a manner stems from his position as an intermediary between the monastery and God. As such, Shenoute purports to communicate only on behalf of God. He speaks not his own words but rather direct, divine revelations. This is an aspect of Shenoute's rhetoric that has already been examined by Stephen Emmel and Rebecca Krawiec but nonetheless deserves further comment as an explicit element of the genre of prophetic judgment oracles. ${ }^{40}$ In the extant fragments of the first letter of Canon 1, Shenoute usually cites the Bible as the authority for his criticisms, using phrases such as, "as it is written," to indicate that he is citing a scriptural text. Shenoute also contends that he has received divine revelations that have been communicated directly to him from God. Shenoute thus models his own prophetic judgments on the judgment oracles of the prophetic authors he explicitly quotes elsewhere in Canon 1. In one of Shenoute's accounts of his argument with the father of the monastery, he describes these messages from God: “. . . I was able to see visible things and revelations of the Lord." ${ }^{41}$ In another description of the dispute, he twice insists that his accusations of sinful activity in the community are true and authentic because they come "from God." 42 When recounting this particular conversation with his monastic father, Shenoute repeatedly emphasizes his own humility in approaching the father about this matter; Shenoute presents himself as a sinner, a child speaking to his father, a man afflicted as if wounded by a sword. ${ }^{43}$ His outward humility, however, is but a Trojan horse that only momentarily disguises the stinging rebuke he hands the monastery's leader. He portrays himself as the modest vessel through which God has delivered his message and thereby uses his humility to prove the authenticity of his own revelations and to undermine his superior's authority. Implying that the monastery's leader really does know about the events that distress Shenoute, he asks, "Does not God speak with ash, or reveal a thing to dust?

38 Shenoute, Canon 1, XC 60 in Munier, Маnu-

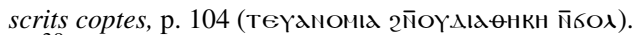

39 Shenoute, Canon 1, YG 217, unpublished (FR-BN

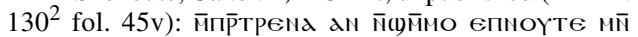

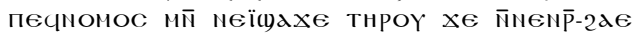

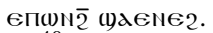

40 Emmel, "Shenoute the Monk"; Krawiec, Shenoute and the Women, pp. 55-66.

41 Shenoute, Canon 1, XB 83, unpublished (FR-BN

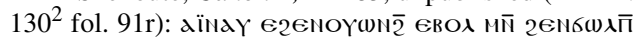
євох йтєпхоїс. See also Emmel, "Shenoute the
Monk," p. 160. Unfortunately, this section of Canon 1 is fragmentary, and the folio that contains this passage

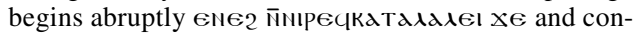
tinues with the line quoted here about the visions.

42 Shenoute, Canon 1, YW 79 and 80, unpublished

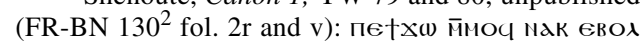
2Ітйпноүте.

43 Shenoute, Canon 1, YW 78-79, unpublished (FRBN $130^{2}$ fols. $1 v-2$ r). See also the discussion of this passage in Emmel, "Shenoute the Monk," p. 163. 
(Gen. 18:27) And if God will speak to me, or if he will reveal something to me, then he will have spoken indeed with you, and he will have revealed to you every matter in this way, since you are a righteous man." ${ }^{44}$ Dripping with irony, Shenoute's words expose what is to Shenoute the real state of affairs in the monastery; the true representative of God in the community is not its leader. God indeed has spoken to Shenoute, giving him the authority to confront the monastery's father, and Shenoute has used his divine revelations to shame him and undercut his authority.

Shenoute attributes his own form of judgment oracles to God's revelation as well and asserts that visions of the impending punishment of the monastery come directly from God. In the first letter, Shenoute insists that the words he speaks and writes are not "parables" or unrecognizable speech. ${ }^{45}$ Here he seems to be answering possible accusations that his warnings are his own fabrications. His claims to the status of a divine intermediary come more forcefully in his second letter, suggesting that during the intervening time, some people in his community found his judgment oracles to be less than convincing. Shenoute responds by asserting that his visions come directly from God. For example, at the end of an allegory about people who are carried off as prisoners and sinners who become pits entrapping others, Shenoute reminds his fellow monks that they had been warned about sins in the community before. But, he argues, they had refused to believe that his warnings were the word of God. "It is the Lord who spoke concerning these matters among you, so that he might inform you of some evil things that exist among you." If the monks had only listened to Shenoute's earlier messages from God, they could have recognized the sinners among them. ${ }^{46}$

Thus Shenoute presents himself as a peripheral Mosaic prophet who is engaged in all of the recognizable elements of prophetic activity. He portrays himself as a politically and socially marginalized figure. He acts as a divine intermediary, communicating revelations from God to his community. He gives and interprets God's law, and he advocates reform in his society, including a return to the true covenant between God and his community. Another important aspect of Shenoute's prophetic self-fashioning is his use of the rhetoric of sexuality to describe the breach between God and the community.

\section{The Monastery AS WhORE}

Understanding Canon 1 as a performance of prophetic activity on the part of Shenoute opens up a new way to understand the sexual language in these two letters. Shenoute adapts for his own use another discourse common to the prophetic books of the Bible-sexual infidelity as a symbol for the community's disobedience to God. Shenoute in fact quotes some of the most famous passages in the prophetic books on this topic: Hosea 1-3, Jeremiah 2-5, Ezekiel 16, and Ezekiel 23. Feminist biblical scholars have already skillfully demonstrated

\footnotetext{
44 Shenoute, Canon 1, YW 81, unpublished (FRBN $130^{2}$ fol. 3r): мн (удрепноүте (удхе мй крмес

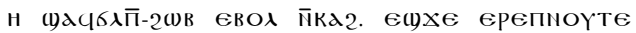

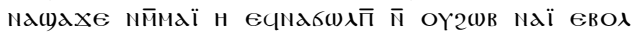

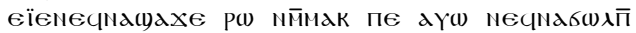

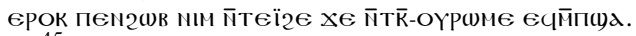

45 "Know that they are not parables, so that you will not say, 'This person opened his mouth over me
}

in parables and a manner of speaking that I do not understand'." Shenoute, Canon 1, XB 148-49, unpublished (FR-BN $130^{2}$ fols. 94v-95r): elme $x \in$ or

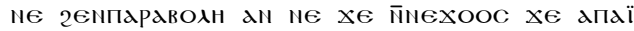

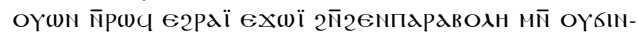

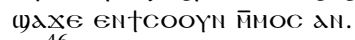

46 Shenoute, Canon 1, YG 174 in Amélineau, Euvres, vol. 1, p. 447. 
the ways in these biblical passages present marriage as a metaphor for the relationship between God and Israel or God and Jerusalem. Israel's or Jerusalem's sins, and particularly sins of idolatry, are framed in sexual terms, such as harlotry, whoring, or adultery. ${ }^{47}$ In the Septuagint, the term used for the bride's sexual transgression is often porneia. ${ }^{48}$ The biblical passages are at times explicit, graphic, and even violent in their descriptions of the sinful woman and her requisite punishment. Likewise, Shenoute's discussions of sexuality and punishment are explicit and graphic in places.

In addition to specific sexual sins described in the rules and elsewhere in Canon 1, Shenoute condemns sexual desire and sexual activity more generally using the term porneia. He also mentions epithumia and pathos. His denunciations of porneia consist of quotations from or allusions to the famous passages on whoring and adultery in Jeremiah, Ezekiel, and Hosea. Shenoute's prophetic speech (and specifically his use of porneia in that prophetic speech) provides an important discursive context for understanding the way that the rest of the sexual discourse in Canon 1 functioned or was heard by his community. His use of the standard tropes of prophetic speech and activity in Canon 1 combined with his explicit citation of prophetic passages in which porneia is a metaphor for the community's fractured relationship with God suggest that sexual discourse is also a discursive trope for Shenoute. Shenoute follows the model of the prophets in using porneia as a metaphor for the monastery's disobedience. Through the motif of porneia, Shenoute simultaneously condemns the monastic community for its transgressions against its covenant with God and constructs the community as an undisciplined, feminine, and subordinate subject in need of discipline and punishment.

I have found seven instances in Canon 1 in which Shenoute mentions porneia or its related forms. In each case, the term arises in a section of Canon 1 that either quotes from or uses motifs originating with the famous passages in Jeremiah, Ezekiel, and Hosea. I have already addressed one such case, when Shenoute condemns porneia and cites a passage from Hosea. In an unfortunately fragmentary folio of Canon 1, Shenoute quotes "the word that is written," in Hos. 6: 10: "They committed lawlessness in the house of Israel. I saw in your dwelling place fornication (porneia)." ${ }^{49} \mathrm{He}$ then writes that those who "defiled themselves among you . . . supported their lawlessness with a false covenant." 50 As I have already discussed, covenantal language and prophetic language portray the actions of the monastery as the adoption of a false covenant; further, this false covenant is articulated as "fornication," or porneia, in an interpolation of Hos. 6:10.

Four other mentions of porneia appear in an extended Shenoutean judgment oracle in the middle of the first letter. This lengthy passage is an excellent example of Shenoute's

47 The scholarship on this topic is vast. Classic texts include Phyllis Bird, “'To Play the Harlot': An Inquiry into an Old Testament Metaphor," in Peggy L. Day, ed., Gender and Difference in Ancient Israel (Minneapolis, 1989), pp. 75-94 and T. Drorah Setel, "Prophets and Pornography: Female Sexual Imagery in Hosea," in Letty M. Russell, ed., Feminist Interpretation of the Bible (Philadelphia, 1985), pp. 86-95. Other studies include Julie Galambush, Jerusalem in the Book of Ezekiel: The City as Yahweh's Wife, Society of Biblical Literature, Dissertation Series, no. 130 (Atlanta, 1992); Yvonne Sherwood, The Prostitute and the Prophet:
Hosea's Marriage in Literary-Theoretical Perspective, Journal for the Study of the Old Testament, Supplement Series 212, Gender, Culture, Theory 2 (Sheffield, 1996).

48 Hosea 1-3, Jeremiah 2-5, and Ezekiel 16 and 23 usually use porneia or other variations of its root. Rahlfs, Septuaginta, vol. 2, pp. 490-92, 657-66, 79196, 809-12.

49 Shenoute, Canon 1, XC 59 in Munier, Мапиscrits coptes, pp. 103-4.

50 Shenoute, Canon 1, XC 59-60 in Munier, Мапиscrits coptes, pp. 103-4. 
overt adaptation of two prophetic discourses to the situation in the monastery: the tradition of the prophetic judgment oracle and the metaphor of sexual infidelity. This judgment oracle occurs immediately after one of Shenoute's accounts of an argument with the monastic leader. It contains visions of a burning orchard, serpents, and beasts. ${ }^{51}$ Shenoute subtly positions his own visions and judgments of the monastery within the tradition of prophetic oracles, reminding his audience of the similar warnings they have already received from the scriptures: "What is your worth, oh community, if the curses and the wrathful words that are written in the prophets then fall upon you and your teachers?"52 The monastery's fate, he argues, will mirror that of the biblical communities who refused to heed their prophets: "You did not realize at all that the curse and the wrath of the anger of God is upon you because of all of your abominations, just as they existed over all of the communities that sinned against him from the beginning." 53

Shenoute then articulates these abominations and sins against God as porneia. First, without directly quoting Hosea, Jeremiah, and Ezekiel, he evokes their trope of porneia to explain the monastery's estrangement from God. He demands that his audience recall examples from the scriptures when other peoples were punished for cheating on the Lord. "Nor did you understand that God had prepared himself to come out from your midst, and he made himself a stranger to you because of your fornication (porneia) and your defilement just as he made himself a stranger to all the congregations that existed since the first day." Then Shenoute lists other communities, including Sodom, Gomorrah, and "the race of giants," beginning, "And this is the way that they were destroyed." 54 The "fornication" of the monastery is compared to the sins of other faithless biblical communities. Shenoute refers to the monastery's predecessors in sin with the same term that he uses to name his monastery; they are all "congregations" ( $\overline{\mathrm{N}} \mathrm{C}$ away from God. ${ }^{55}$ The monastic community has chosen fornication and defilement over

51 Shenoute, Canon 1, YW 81-83, unpublished (FR-BN $130^{2}$ fols. 3r-4r); for example, in YW 82:

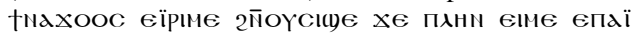

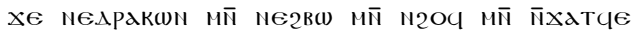

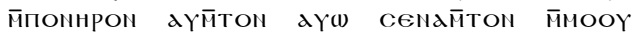

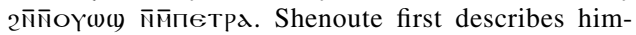
self as "weeping and groaning" and covering himself with dust as he watches a blooming grove burn.

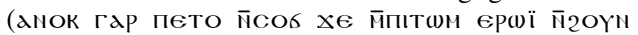

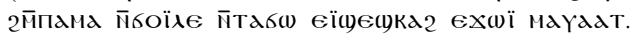

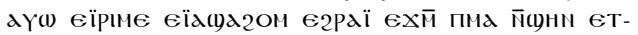

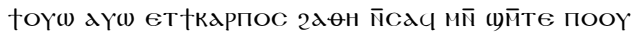

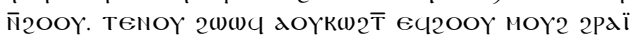
$\overline{\mathrm{N}} 2$ нте $\overline{\mathrm{q}}$ [YW 81]. Cf. Emmel, "Shenoute the Monk," p. 162.)

52 Shenoute, Canon 1, YW 83, unpublished (FR-

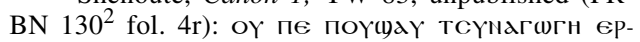

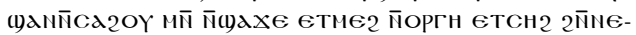
профнтнс є є2раї єхш мй ноүрєч†свш.

53 Shenoute, Canon 1, YW 84, unpublished (FR-

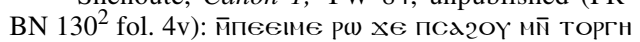
мпбшнт йпноүте є2раї 2Іхш етве поүвоте

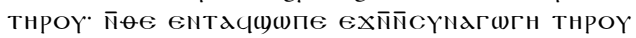

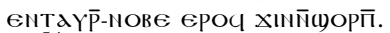

54 Shenoute, Canon 1, YW 84, unpublished

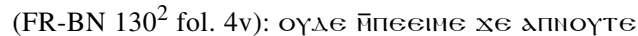

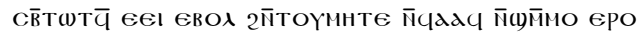

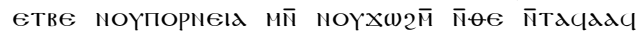

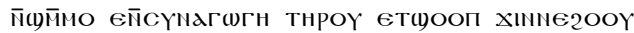

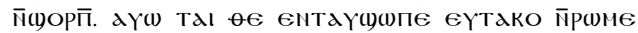

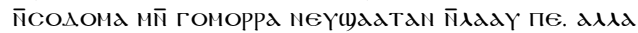

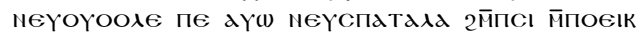
аү(1) Єтвє nеYнOBє....

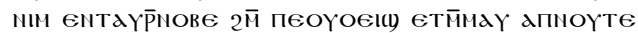

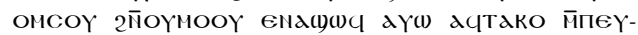
ке(нर 2 Іоүсоп.

55 сүндГшгн is the technical term Shenoute uses for the monastic community, comparable to the Pachomian usage of "koinonia." It appears in Shenoute's texts in the singular and the plural, referring either to the entire monastery (the singular тсүнагшгн) or the collection of at least three residences-two for men, one for women-that comprised the community (the plural т̄сүндг(ген). See also Bentley Layton, "Social Structure and Food Consumption in an Early Christian Monastery: The Evidence of Shenoute's Canons and the White Monastery Federation A.D. 385-465," Le Muséon 115 (2002): 26, and Emmel, "Shenoute the Monk," pp. 158-59. 
fidelity to God, and God will in turn become "a stranger" to the monastery as he did to the others.

Further along in this extended judgment oracle, ${ }^{56}$ to underscore the consequences of their disobedience, Shenoute turns again to the motif of porneia, using the term (or its related verbal form) three times in succession, in a passage that resonates with biblical references. He compares the monastery to three biblical figures: the sinful Judah in Jeremiah 17, the whore in Ezekiel, and the whore in Hosea. Shenoute begins with idolatrous Judah, whose sin, according to Jeremiah 17 , is indelibly recorded on its heart. Shenoute paraphrases Jer. 17:3, asking, "Indeed, are you better than or do you surpass this one whose treasures the Lord gave for spoil as the price because of all of the sins that she committed in all her territory?" Shenoute goes on, comparing the monastery next to the whore of Ezekiel 16 and 23. With irony he asks again, "Or are you different from this one whom the Lord handed over into the hands of the ones who hated her, who took her labors and all of her afflictions, who stripped her naked of her garments? They made her shameless (Ezek. 16:39; 23:26, 29)." $\mathrm{He}$ continues, writing that the "disgrace of her fornication (porneia)" was revealed "because of her fornication that she fornicated." He adds, "She followed the peoples (ethnos), and she was defiled by her heart's desire." Finally, Shenoute raises up the example of the whoring wife of Hosea 2:

You are not more beautiful than this woman who sinned before God, are you? ... God took from her her grain, her oil, her wine, and her things, and her clothing (Hos. 2:9). He kept her according to the days of her giving birth, and according to the days when she came out of the land of Egypt (Hos. 2:15), as he [punished] her in the days of the Baals when she sacrificed (Hos. 2: 13).$^{57}$

${ }^{56}$ In the intervening folios, Shenoute praises faithful biblical exemplars (such as Noah and Abraham) and condemns the impious. Shenoute, Canon 1, YW 85-87, unpublished (FR-BN $130^{2}$ fols. 5r-6r): for example,

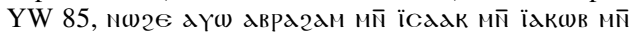

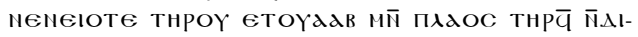

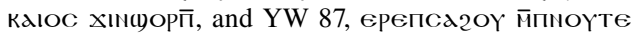
2й̄̄нї їндсевнс (Prov. 3:33). He then summarizes his sentiments by urging the community not to "trust" itself and reminds the monks of their "abominations." Shenoute, Canon 1, YW 87, unpublished (FR-BN $130^{2}$ fol. 6r): Етвє паї ТсүнаГшГн мпПркапоүна2те 2l(w-

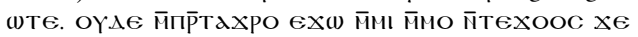

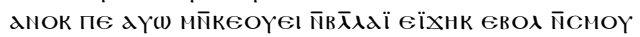
нім. ерєюооп ерої гйноүвоте.

57 Shenoute, Canon 1, YW 87-88, unpublished (FR-

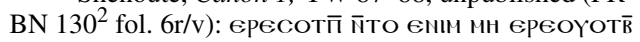

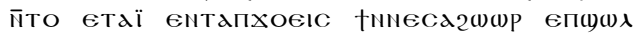

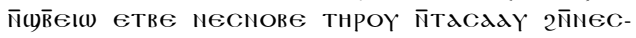

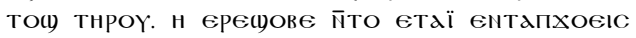

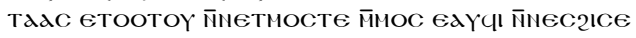

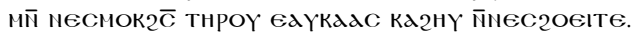

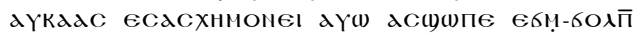

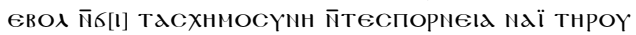

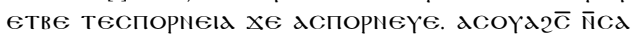

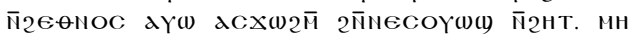

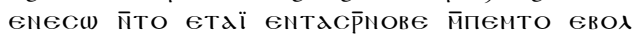

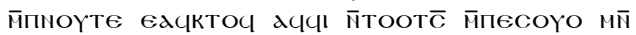

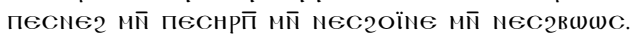

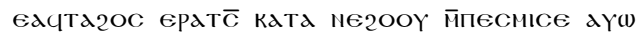

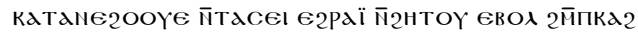

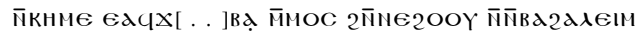

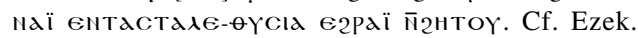
16:39, NRSV: I will deliver you into their hands, and they shall throw down your platform and break down your lofty places; they shall strip you of your clothes and take your beautiful objects and leave you naked and

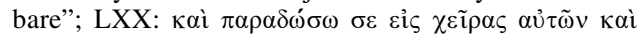

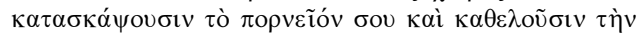

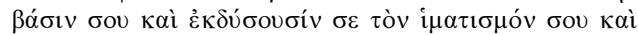

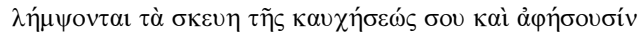

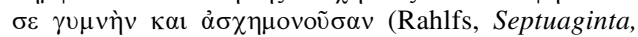
vol. 2, p. 794): Bohairic: еı† ймо етрні еноүхіх еүеяомяем йпепорніо оүо2 еүени епеснт

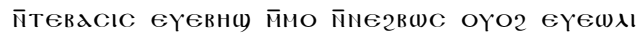

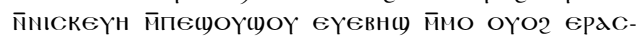
хнмосүнш (Henricus Tattam, ed., Prophetae Maiores in Dialecto Linguae Aegyptiacae Memphitica seu Coptica, 2 vols. [Hildesheim and New York, 1989], vol. 2, p. 72). Cf. Ezek 23:26, 29, NRSV: "They shall also strip you of your clothes and take away your fine jewels ... and they shall deal with you in hatred, and take away all the fruit of your labor, and leave you naked and bare, and the nakedness of your whorings

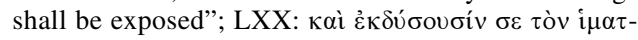

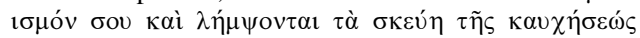

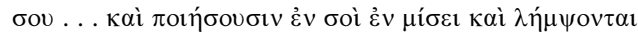

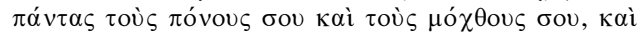


Shenoute shames the monastery by comparing it first to idolatrous Judah and then to biblical harlots. Through these passages, he, like the biblical texts before him, links porneia to idolatry and thus suggests that he uses the motif of porneia not to condemn sexual sins specifically, but to issue a broad indictment of disobedience more generally. Shenoute uses these charged biblical passages as a model for what the community has become and also, possibly, as a grain of hope that God might woo back the monks of the monastery, as he did the whoring wife of Hosea $2 .{ }^{58}$

The final two mentions of porneia actually appear first in the text of Canon 1. I treat them last because they are the most elusive of Shenoute's biblical references to porneia. They occur a few pages after his intertextual reading of Jer. 6:11 and the monastic rules. He has followed this homiletic section with a series of descriptions of the ways in which the monastery, an ostensibly holy, ascetic community, is in reality filled with hypocrisy. Despite claiming to be monks, the community has sinned through "fornications (porneia), pollutions, and deceits." ${ }^{59}$ Shenoute then draws on motifs present in Jeremiah 2 in order to chastise the monks for throwing away the opportunity for salvation that God has granted them. Although he never directly quotes Jeremiah 2, the similarities are nonetheless striking. Their shared themes include God's deliverance of his people from suffering and the community's "whoring" behind God's back despite this deliverance. According to Jeremiah, God has led Israel out of Egypt, and yet Israel has forsaken God by worshiping other gods, by acting like an ass in heat, and by having the audacity to deny her defilements. Shenoute asceticizes the biblical prophet's tale of Israel forsaking the promised land with her whoring:

Whether they were barbarians, or robbers, or soldiers, or rich men, or many temptations, God saved you from them many times when he made you worthy of this life now, which you are in, and he blessed you in order that you might not lack bread or clothing or any other thing at all of the earth, because of the righteousness of your holy fathers, not you. Whether it was the devil, or demon, or unclean spirit, or defilement, or theft, or every sinful temptation, you gathered them to you in order

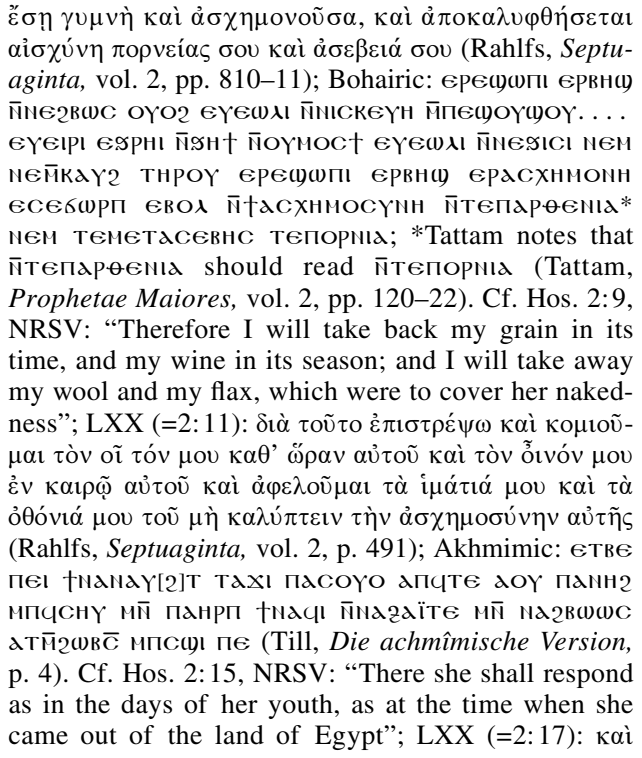

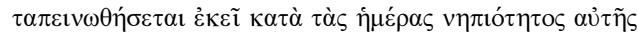

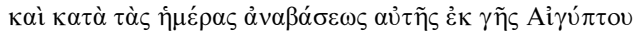
(Rahlfs, Septuaginta, vol. 2, p. 492); Akhmimic: dү(1н2

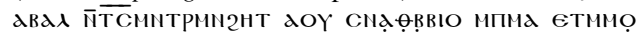

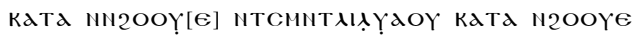

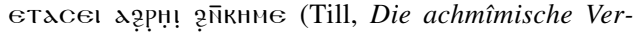
sion, p. 5). Cf. Hos. 2: 13 NRSV: "I will punish her for the festival days of the Baals when she offered incense

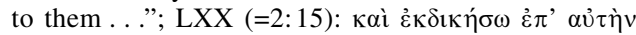

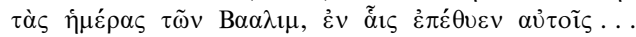
(Rahlfs, Septuaginta, vol. 2, p. 491); Akhmimic: doץ

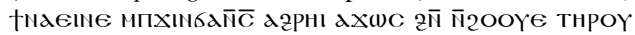

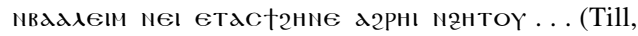
Die achmîmische Version, p. 5).

${ }^{58}$ From there, Shenoute begins a criticism of the monastery not for sexual sins, but, as Emmel has described the passage, for wasteful building projects; the monastery should have used their resources for charity to the poor. Shenoute, Canon 1, YW 88-90, unpublished (FR-BN $130^{2}$ fols. 6v-7v); a description of the passage appears in Emmel, Shenoute's Literary Corpus, vol. 2 , p. 560 .

59 Shenoute, Canon 1, XC 27 in Leipoldt, Opera Omnia, vol. 3, p. 205. 
that you might be afflicted, despoiled, and trampled. Whether it was a hardening of the heart, or folly, or ignorance, or fornication (porneia), or quarrelling, or great impiety, God bore you out from them though you committed them in your worldly, beastly condition. Whether wisdom, knowledge, adornment, holy commands, virginity, or other wondrous works that you knew-all of them-when the Lord made you worthy of this ordination now, when he brought you to it, yet you returned according to what is written, to your ways again. The grace of monasticism to which you were summoned-you defiled it, and you polluted yourself in great and many evils that you committed in your worldliness. . . . ${ }^{60}$

Where in Jeremiah, chapter 2, God has delivered Israel from Egypt into a "plentiful land," for Shenoute, God has delivered the monks into an ascetic promised land. Just as in Jeremiah Israel "defiled" that plentiful land with its "abominations," so too have the monks committed "defilements" and sin. And just as Israel "played the harlot," so too have the monks, among other sins, abandoned their virginity for defilement and porneia. Israel is compared to a camel or a lustful ass, while Shenoute decries his monastery's "worldly, beastly condition." Although it is difficult to pinpoint any precise biblical quotation in this passage of Canon 1, Shenoute's adaptation of prophetic discourse, and particularly the themes of Jeremiah 2, is evident.

Shenoute's references to pathos, or passion, outside of the monastic rules also evoke the prophetic metaphor of porneia. As with porneia, he draws a connection between pathos and disobedience. "Lawlessness" ensnares people who "[have n]ot obeyed [th]ose who [hear th] eir father, who is God, while they are bound in their passions (pathos) and their perfidies." 61 Whether "passion" is a cause, effect, or mere characteristic of this lawlessness and disobedience is unclear; again, sexual rhetoric functions as a general signifier of broad scale disobedience or "lawlessness." 62

Shenoute's adaptation of the prophetic theme of porneia in Canon 1 illuminates a deeper ideological or theological reading of Shenoute's sexual discourse. As in Jeremiah, Hosea, and Ezekiel, sexual transgressions are manifestations of a symbolic adulterous desire that breaches the ideal relationship of fidelity between God and his people. In Canon 1, as in Hosea and Jeremiah, breaking the covenant "amounts to religious harlotry or adultery," 63 or, in the language of the Septuagint and Shenoute, porneia. Shenoute directs his criticism at all of the monks, regardless of their gender, and thus charges the community as a single unit of porneia. Throughout much of Canon 1, he directs his speech to the monastery in the second person singular. ${ }^{64}$ The "you" of his accusations consists not of multiple individuals but of the one, whole community. Moreover, this "you" is gendered as feminine. On the

60 Shenoute, Canon 1, XC 27-28 in Leipoldt, Opera Omnia, vol. 3, pp. 205-6. Wiesmann also notes a resemblance to Jer. 2:36 in his Latin translation of Leipoldt's text (H. Wiesmann, trans., Sinuthii Archimandritae Vita et Opera Omnia, 2 vols. (numbered 3 and 4), CSCO 96, 108, SC 8, 12 [Louvain, 1953], vol. 3, p. 121). See also Emmel, "Shenoute the Monk," pp. 161-62, n. 28, regarding the interpretation of космікон as referring to nonmonastics.

61 Shenoute, Canon 1, YG 128-29 in Elanskaya, Literary Coptic Manuscripts, p. 234; English translation in ibid., p. 237.

${ }^{62}$ See also Canon 1, YG 173 in Amélineau, Euvres, vol. 1, p. 446. Shenoute characterizes people who re- fused to believe his warnings about sin in the community as "very deep pits" and people "who want to fulfill their passion (пдөос)." Again, due to Shenoute's heavy use of symbolism throughout this section of Canon 1, it is difficult to ascertain whether Shenoute accuses the community specifically of sins that arise from "passion" (such as sex). Regardless of the actual social circumstances of this line, Shenoute's usage of pathos certainly would have functioned rhetorically for his audience much like the porneia passages from Hosea and Ezekiel.

63 Lundbom, Jeremiah, p. 142.

64 See also Emmel, "Shenoute the Monk," p. 158, n. 16. 
most simplistic level, the very term Shenoute uses to name the monastery- тсүндгшгнis feminine, and thus when Shenoute addresses the monastery in the second person singular in his letters, he usually uses the second person feminine singular pronoun. But on a more complex and compelling level, his use of the motif of porneia genders the community as a feminine subject. Shenoute's prophetic and sexual rhetoric feminizes the monastery as it implicitly compares the community to a fornicating whore. Like the whores of Hosea, Ezekiel, and Jeremiah-whores that Shenoute explicitly mentions in his own textsShenoute's monastery has become a highly sexualized entity, easily swayed by seductive deceivers. The monastery, although comprised of both male and female monks, is in fact gendered as feminine.

Feminist biblical criticism has identified some ideological implications of this gendering discourse in the Prophetic texts that might also illuminate Shenoute's writings. As Athalya Brenner has argued, the sexualized language establishes a rhetorical and gendered division between male and female subjectivity in which the reader is invited to identify with the male textual voice. The masculinized author/reader is "divine, correct, faithful, positive, voiced." The feminized subject is "human, morally corrupt, faithless, negative, silent or silenced." ${ }^{65}$ The effect of the sexualized rhetoric in the Prophets, and in Shenoute, is a totalizing discourse that places the subject of critique in a position subordinate to the author and thus also in a position subordinate to the reader, who identifies with the author, who constructs that subject as an uncontrolled woman that all readers should recognize as in need of punishment and discipline. Thus, the gendered implications of Shenoute's rhetoric of porneia and other sexual sins rhetorically and ideologically enhance his larger claim in Canon 1 that the monastery is in need of greater discipline-discipline that he claims the current monastic leadership has failed to provide.

\section{Conclusion}

To return to the question that I sidestepped at the beginning of this paper-does Shenoute's sexual rhetoric answer the question debated by Ladeuze and Amélineau, "Did they or didn't they... ?"- - one might argue that Shenoute simply uses these passages from Jeremiah,

65 Athalya Brenner, "Pornoprophetics Revisited: Some Additional Reflections," Journal for the Study of the Old Testament 70 (1996): 63-64. See also Peggy L. Day, "The Bitch Had It Coming to Her: Rhetoric and Interpretation in Ezekiel 16," Biblical Interpretation 8 (2000): 231-54, and Brenner's more recent monograph, The Intercourse of Knowledge: On Gendering Desire and 'Sexuality' in the Hebrew Bible, Biblical Interpretation 26 (Leiden, 1997). Heike Behlmer has provided a revealing analysis of the ways in which Besa, Shenoute's successor as monastic leader, adopted this same rhetorical strategy in letters to women monks decades later (Behlmer, "The City as Metaphor in the Works of Two Panopolitans: Shenoute and Besa," in A. Egberts, B. P. Muhs, and J. Van Der Vliet, eds., Perspectives on Panopolis: An Egyptian Town from Alexander the Great to the Arab Conquest, Papyrologica Lugduno-Batava 31 [Leiden, 2002], pp. 13-29). Behlmer eloquently sums up the effects of the portrayal of a monastic community as a "promiscuous wife" or a "raped virgin" who, in the rhetoric of both the Hebrew Bible and Besa, deserved her abuse and who was analogous with the city of Jerusalem in the biblical prophets: "The choice of the citymetaphor and its traditional connotations in particular would have been a very good means to provide reassurance and restore a feeling of superiority and control. The ancient city was a beautiful female, to be conquered by violence, to be governed and regulated by males" (p. 27). Behlmer's study addresses the gendered implications of letters that Besa wrote specifically to women, noting that the "[g]endered reproaches and threats" in Besa's adaptation of the biblical metaphor were probably "especially effective in silencing a female opponent" (p. 27). In Shenoute's case, the rhetoric serves first to feminize his opponents, some of whom are male. 
Ezekiel, and Hosea precisely because they contain explicit sexual references. Perhaps they would therefore resonate particularly well with a community that is plagued with instances of sexual sin. ${ }^{66}$ Thus, perhaps Shenoute adapts the biblical trope of porneia to condemn actual acts of illicit sex that have occurred in the monastery. Certainly, understanding that Shenoute's condemnations of fornication and deception draw upon deeper, historical narratives of Israel's relationship with God does not diminish their more carnal resonance within an ascetic community. Nor does it preclude a more literal reading of Canon l's letters as denunciations of sinful acts committed by monks whose very identity is determined by their vows to chastity, poverty, obedience, and faith. In the social context of early Christian monasticism, an institution steeped in the textual world of the Bible, Shenoute's language would have been interpreted multireferentially ${ }^{67}$ The monks may have understood that he was not referring to specific sexual acts by specific monks. Or knowledge of the commission of these sins may have been so widespread that his audience understood what seem to us to be rather oblique references. Yet I do insist that the prophetic context of Canon 1 cannot be obscured or dismissed in favor of a more literal reading of the texts. Arguably, neither prophecy nor porneia is simply an "issue" Shenoute is trying to address in Canon 1. They are rhetorical devices employed to achieve some kind of social and structural reform in the community. Shenoute write these letters as acts of prophetic speech, of which porneia was only one of the prophetic discursive elements he utilized. It is an element of discourse that he used to great effect to criticize the current monastic leadership and agitate for change in the monastery.

\footnotetext{
66 In fact, I myself have done so to a small degree in an earlier publication (see my "Purity and Pollution").

67 The verisimilitude of biblical world to monks is evident in Besa's vita of Shenoute. The prophets Elijah, Elisha, and John the Baptist reportedly visited the monastery one evening. Besa, Vita Sinuthii, 118, in Lei-
}

poldt, Opera Omnia, vol. 1, pp. 54-55; English translation in David N. Bell, The Life of Shenoute by Besa, Cistercian Studies Series 73 (Kalamazoo, Michigan, 1983), p. 76. I thank Mark Swanson for calling my attention to this passage. 